OPEN ACCESS

Edited by:

Luxon Nhamo,

Water Research Commission,

South Africa

Reviewed by:

Mengru Wang,

Wageningen University and Research, Netherlands Mahdi Asgari,

University of California, Riverside, United States

*Correspondence:

Vincent Linderho vincent.linderhof@wur.n

Specialty section

This article was submitted to Water and Human Systems, a section of the journal

Frontiers in Water

Received: 05 July 2021 Accepted: 20 October 2021 Published: 16 November 2021

Citation:

Linderhof $V$, de Lange $T$ and Reinhard S (2021) The Dilemmas of Water Quality and Food Security Interactions in Low- and

Middle-Income Countries. Front. Water 3:736760. doi: 10.3389/frwa.2021.736760

\section{The Dilemmas of Water Quality and Food Security Interactions in Low- and Middle-Income Countries}

\author{
Vincent Linderhof*, Thijs de Lange and Stijn Reinhard \\ Wageningen Economic Research, Wageningen University and Research, The Hague, Netherlands
}

Water is a factor input for many food system activities such as agriculture, food processing and consumption. However, food system activities also affect water resources. Moreover, the shift in focus of food security in Low- and Middle-Income Countries (LMICs) from producing enough staple foods toward healthy diets stimulates local production of fresh food such as fruit, vegetables and fish even in water scarce regions. To secure local production, polluted water is used for food production, processing and consumption, which might jeopardize human health. However, scientific evidence is still scattered and fragmented. The aim of this study is to systematically investigate the empirical tested impacts of water quality on the food system activities and vice versa. Using a comprehensive framework, we sketch the inter-relationships between water quality and food systems based on a literature study. Food system activities included food production (crop production, livestock and aquaculture), food processing, and food consumption. Multiple contaminants were incorporated such as nitrogen, phosphorus, pesticides, pathogens, cyanotoxins, and heavy metals. Moreover, we considered different water sources such as groundwater, surface water, wastewater and coastal water. We found that food system activities contaminate water in several ways, and these differ between food system activity and type of food produced. The impact of water quality on the food system depends on the food produced, the type of contaminant and techniques of food preparation. In addition, food is contaminated in multiple ways along the food system. Irrigation with polluted water may sound familiar, but polluted water is sometimes also used in food processing (cleaning of equipment or food products), and in food preparation (at home or by street vendors). Hygiene in food consumption is crucial to prevent fecal-oral transmission. However, water, sanitation and hygiene (WASH) received little attention in relation to food consumption. If local production of fresh food is encouraged to improve food security, all aspects of water quality should be analyzed to avoid undesirable consequences.

Keywords: food security, water quality, food systems, water resources, tradeoffs, LMICs 


\section{INTRODUCTION}

Food systems and water resources are highly related. Water resources supply water as an essential input to food systems activities (FAO, 2017) such as: agricultural production, aquaculture, food processing and food consumption, and in achieving food security i.e., the Zero Hunger Sustainable Development Goal (SDG2). Reversely, food system activities also affect water resources by depleting groundwater, nonpoint source pollution from agriculture (FAO IMWI, 2017) or discharges of untreated or poorly treated wastewater. Thus, sustainable management of water resources is crucial, and still many challenges exist to realize the level of sustainable water resources as suggested by the Clean Water Sustainable Development Goal (SDG6) (Damania et al., 2019). For instance, water quality issues negatively affect the production processes of drinking water and water use in food industry. As the food system and the water system are interlinked, this should also be reflected in managing both systems.

Over the last decades, the focus of food security shifted from producing enough staple foods toward ensuring healthy diets for all. Next to eating enough and a balanced number of calories, the emphasis is nowadays also on a balanced diet with respect to nutritional value of diets (e.g., avoid micro-nutrient deficiencies for a healthy lifestyle). The EAT-Lancet report, published early 2019, emphasized the importance of diverse diets for health and connect these healthy diets to sustainable food systems (Willett et al., 2019). Nonetheless, the report discussed how unsustainable agricultural practices, like the overuse of fertilizers or pesticides, might lead to pollution and affecting soil and water quality through leaching and runoff. However, the impact of water pollution on consumers health was beyond the scope of the EATLancet report (Willett et al., 2019). One of the solutions of coping with water scarcity while producing enough food is the use of (un)treated wastewater for irrigation (Qadir et al., 2007; Al Evans et al., 2019), which creates a dilemma if poor quality water is used. Poor quality wastewater might simultaneously cause disruption in crop growing, leave traces of foodborne diseases or residues of toxic substances, which cause animal diseases for livestock, fish and sea-life in the short and/or long run, and affect human health (Amoah, 2011; Woldetsadik et al., 2018), which has a negative impact on food security.

Although the impact of irrigation water quality on agriculture has been investigated for more than a century (Malakar et al., 2019), the impact of the use of polluted water in the food supply system on food security and human health remains a rather underexplored. Moreover, encouraging eating more healthy diets might lead to undesirable trade-offs for consumers, because food items which are considered as healthy from a nutritional perspective, such as fruit, vegetables and fish, are also the food items which are more prone to contamination through the use of polluted water. In particular, the effects on stimulating a healthier diet on consumers health is largely unknown and might even result in the deterioration of the consumers health status, due to water quality issues. More knowledge on the relationship between food security (healthy diets), the food system and the increasing pressure on water resources, both in quantity and quality, is required. Better targeted measures will not only solve water management issues but also improve food security outcomes in multiple ways throughout the food system. Water is a key production factor of many activities of the food system, such as agriculture, food processing and consumption (van Berkum et al., 2018). Additionally, food systems activities affect water resources through the emission of pollutants.

The aim of this study is to systematically analyze the empirical tested impacts of water quality in the food system and, vice versa. With a framework combining the food systems and the water systems the complex interrelations between water quality issues and the aforementioned components of food security are structured. With a literature review, we provide examples of the complex relationships between water resources and all components of the food system. In particular, we search for empirical tested impacts of water quality issues on food products. Impacts of poor farming practices on food products is beyond the scope of this study. Moreover, contamination of food can sustain throughout all elements of the food system, although preparation of food might alleviate the impact of contamination.

The structure is as follows. Material and Methods section discusses the concepts of the food systems approach and water management issues. The results from the literature review are presented in Results section. Section Discussion discusses our findings and concludes.

\section{MATERIALS AND METHODS Framework to Link Food Systems and Water Systems}

This study aims to provide more insights in the relationships between water quality and food security through the food system. This is a two-way relationship (i) water resources are used within food system activities, such as agriculture, aquaculture, processing and consumption, and the quality of the water resources affects the quality of food products in those food system activities, (ii) food system activities cause pollution, which affects water resources through runoff and leaching of residues of fertilizer and pesticides, discharge of wastewater of food processing manufacturers and consumers to surface water. In the literature, there are many examples of how water quality relates to aspects of the food production or food consumption. With a combined framework of food systems and water systems, we review the literature to cover all aspects of water quality affecting or affected by food system activities.

For this review, we introduce a framework that combines the food activities of the food system approach (van Berkum et al., 2018) with the different water resources, see Figure 1. It distinguishes five elements of the food supply chain including (i) agriculture and aquaculture, (ii) food storage, transportation and trade, (iii) food processing, (iv) food retail and provisioning, and (v) food consumption. In the food system approach, water systems are part of the environmental drivers. In this study, we distinguish four water resources, namely ground water, surface water, wastewater and coastal waters, because these interact differently with food system activities, see Figure 2. For 


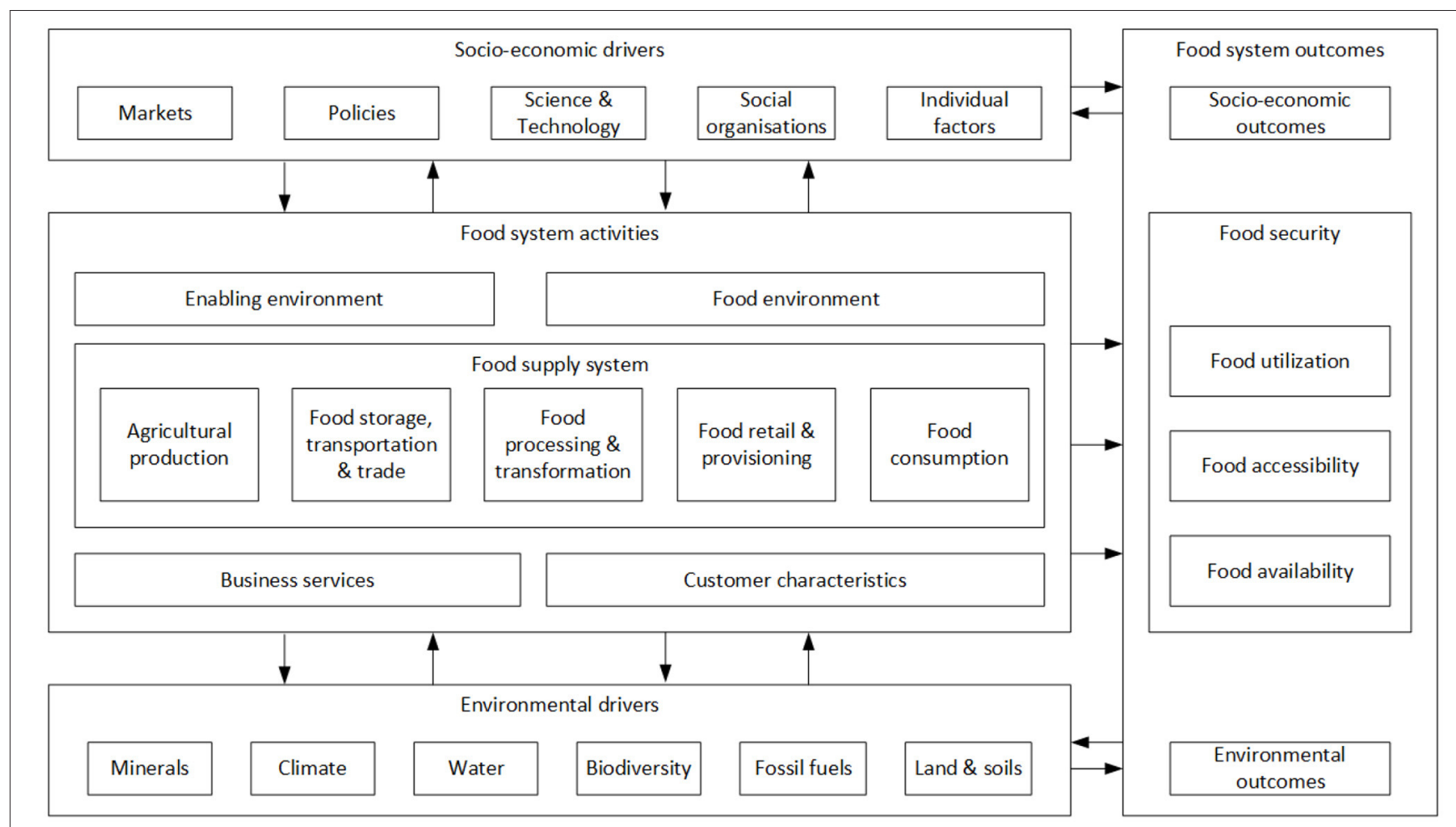

FIGURE 1 | Food systems framework. Source: van Berkum et al. (2018).

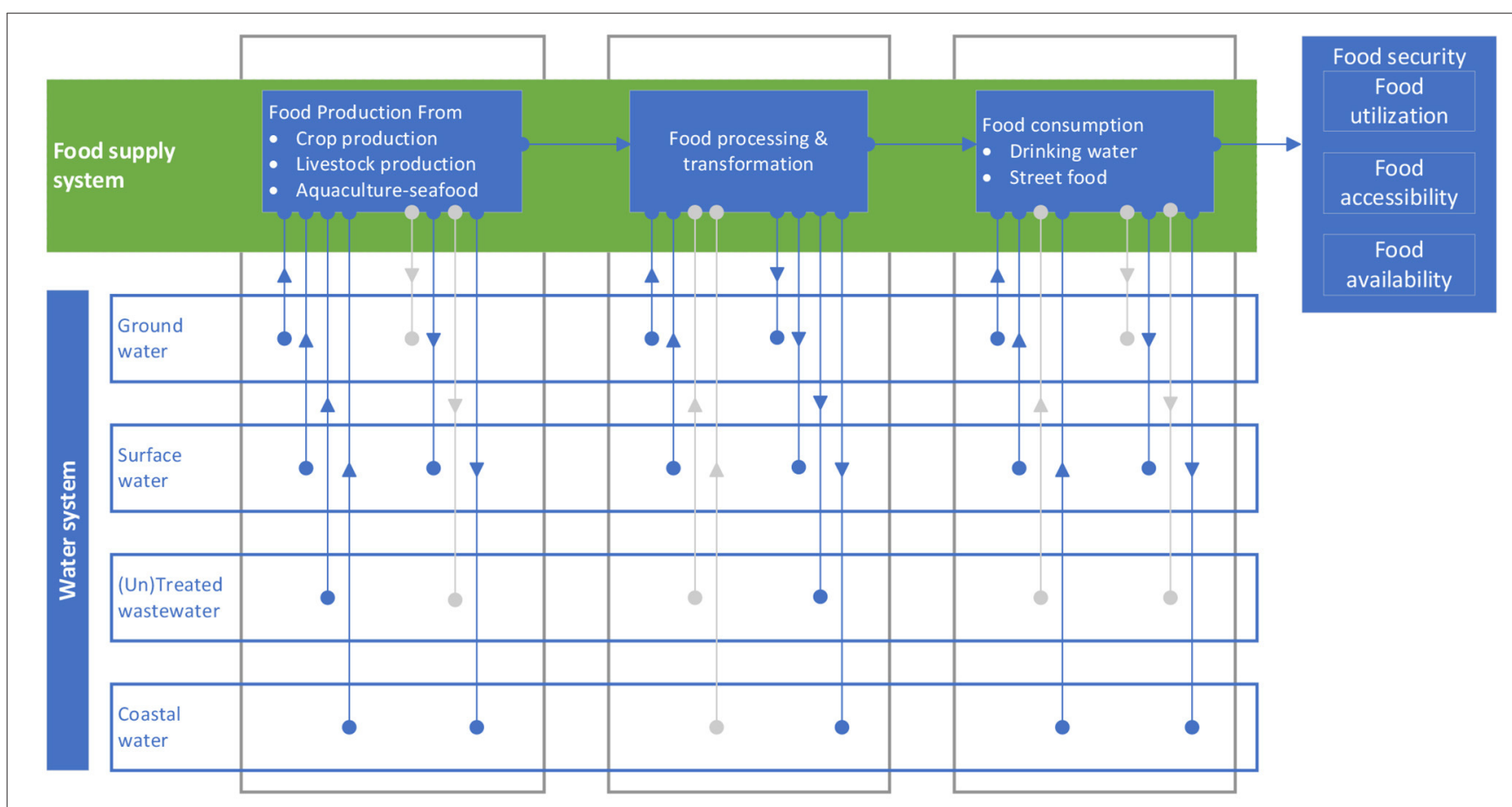

FIGURE 2 | Framework of water systems and food systems relating to water quality (storage and distribution, and food distribution not included). Derived from de Lange et al. (2021). 
convenience, we neglected the food system activities food storage, transportation and trade" and "food retail and provisioning," because those activities have no or little interaction with water resources.

Not all connections between food system activities and water resources will be relevant. Figure 2 depicts the most relevant ones, which we will use to structure of reviewing the literature. The colour of the arrows indicates the expected interaction. A blue arrow means that a significant interaction is expected, and a grey arrow means that no or modest interaction is expected. Note that we only considered direct impacts of water discharges or pollution of water resources. Ground water resources are most often affected in indirect ways through surface waters or soils.

When we take a closer look into the different food systems aspects, we can distinguish sub-activities. For agriculture and aquaculture, we consider crop production, livestock production and aquaculture and seafood production. Irrigation water from surface water ground water and wastewater, is used in crop production. The overuse of fertilizer and pesticides in crop production affect the soil and surface waters. In the case of livestock production, water is mainly used for drinking water of livestock. The manure of livestock might leave residues in soil and surface waters. Finally, aquaculture and seafood are produced in surface water (in-land aquaculture) or coastal waters (aquaculture and seafood). In inland aquaculture, fertilizer and herbicides are used for growth and health of the shrimps and fish produced. After harvesting, the water is discharged to surface water.

In food processing, water is largely used as input, intermediate transport or for cleaning. All activities have their own water quality requirements (Kirby et al., 2003). Ground water and surface water resources are mainly used as input, see blue arrows from ground waters and surface waters toward food processing in Figure 2, although the use of treated wastewater might be underdeveloped due to higher water quality standards for food processing. Through wastewater discharge, the food processing activities in the food system have a negative impact on the quality of all water resources, i.e., blue arrows from food processing to all water resources. Wastewater is discharged indirectly through a sewage system, if present, or directly to the water system.

Food consumption uses tap water (or other available water resources) as an input in food preparation and cleaning activities. The requirements for a good water quality in food consumption are high as in the case of food processing. Tap water or other water resources stem mainly from groundwater and surface water, see blue arrows to food consumption in Figure 2. Through wastewater discharge, food consumption activities at home or in restaurants affect surface and coastal waters, see blue arrows from food consumption to surface water and coastal waters in Figure 2.

\section{Underlying Aspects of the Systems Interaction Between Water Resources}

Next to the interactions between the activities of food system and the water resources, the different water resources interact as well. For instance, surface water or wastewater are sources of groundwater recharge. Ground water can affect surface water.
Due to these interactions poor quality water resources might also affect the quality of the connected water resources. In Kaduna State in northern Nigeria, the Samaru stream, Kubanni River and Kubanni dam are polluted mainly by chemical fertilizers from multiple point and diffuse sources from different water streams (Chigor et al., 2012). Municipal wastewater, sewage from a treatment plant, stormwater runoffs and water from irrigation systems contaminate the three monitored surface water bodies which are used for drinking water and irrigation (Chigor et al., 2012). This example indicates that water quality of different water sources within a water system are interrelated and change over time driven by rainfall, among others.

Upstream food system activities such as the use of agrochemicals, discharge of untreated wastewater, agricultural wastewater and the overuse of a water source (upstream) might lead to salinization of the water resource (FAO, 2011) or pollution of water downstream. Extensive use of ground water resources might lead to an increase of trace elements levels in ground water bodies used for irrigation (Malakar et al., 2019).

\section{Typology of Contaminants}

Water quality can be poor in many respects. Therefore, we selected a number of pollutants which have been indicated to affect food production in previous studies on water quality for irrigation (Malakar et al., 2019). The list of contaminants include; (i) nitrogen and phosphorus; (ii) pesticides and herbicides; (iii) cyanotoxins, which are released by cyanobacteria, which mainly reproduce in water bodies under warm circumstance with high concentrations of nitrogen and phosphorus; (iv) mycotoxins which are chemicals produced by fungal; (v) pathogens; and (vi) heavy metals. Note that, nitrogen and phosphorus, essential nutrients for crop growth, are usually referred to as nutrients in the environmental literature (Hach and Tan, 2007; Amin et al., 2017; Walker, 2019). In this study, however, we reserve the word nutrients for macro- and micro-nutrients essential for human consumption.

The presence of those contaminants in the water source used in the food system might lead to several health issues depending on the type and degree of exposure of the contaminant. In an earlier study, several contaminants of water resources used for irrigation have been listed (Malakar et al., 2019). Not all contaminants have been researched extensively (de Lange et al., 2021) or are irrelevant for in the context of the Global South. Table 1 presents the contaminants that we will consider in this study for the Global South. It presents the expected water pollution sources, the affected water resources and the entry points of water pollution in the food system. These entry points are throughout all activities of the food system, see Table $\mathbf{1}$.

Without discussing the details of the medical literature on the effects of water pollution on human health, we briefly summarize some references of the main human health effects of the pollutants: nitrogen and phosphorus (Qasemi et al., 2018); pesticides (Kim et al., 2017); cyanotoxins and mycotoxins (Funari and Testai, 2008; Zain, 2011; Malakar et al., 2019). Foodborne pathogens include a broad range of bacteria, viruses and parasites. An infection of a foodborne pathogen can affect almost any system in the human body, depending on the specific 
TABLE 1 | Type of water contamination related to food.

\begin{tabular}{|c|c|c|c|}
\hline Pollutants & Source of water pollution & $\begin{array}{l}\text { Water resource prone to presence of } \\
\text { pollutants }\end{array}$ & Entry point in food system \\
\hline Nitrogen and phosphorus & $\begin{array}{l}\text { Overuse of fertilizer and manure in farming } \\
\text { practices }\end{array}$ & Surface water and groundwater & $\begin{array}{l}\text { In nitrogen- and phosphorus poor areas, } \\
\text { nitrogen-rich and phosphorus-rich } \\
\text { irrigation water improves crop productivity }\end{array}$ \\
\hline Pesticides & Overuse of pesticides in farming practices & Surface water and groundwater & $\begin{array}{l}\text { occurrence of residues in food crops like } \\
\text { vegetables due to irrigation }\end{array}$ \\
\hline Cyanotoxins & Surface water & $\begin{array}{l}\text { All freshwater ecosystems, mainly surface } \\
\text { water }\end{array}$ & $\begin{array}{l}\text { Irrigation or processing with polluted } \\
\text { water. Toxins can accumulate in plants, } \\
\text { including food crops and under some } \\
\text { conditions can also inhibit plant growth }\end{array}$ \\
\hline Mycotoxins & Not specified & $\begin{array}{l}\text { Waste water, and surface water affected } \\
\text { by wastewater discharge or animal } \\
\text { excretion }\end{array}$ & Mycotoxin uptake due to irrigation water \\
\hline Pathogens & Surface waters, wastewater & Wastewater & $\begin{array}{l}\text { Irrigation with surface water of freshly } \\
\text { eaten produce (overhead sprinklers } \\
\text { increase incidences of contamination) }\end{array}$ \\
\hline Heavy metals & $\begin{array}{l}\text { Groundwater and surface water with } \\
\text { industrial wastewater discharges }\end{array}$ & $\begin{array}{l}\text { Groundwater for irrigation and drinking } \\
\text { water }\end{array}$ & $\begin{array}{l}\text { Hheavy metals are an essential for plant } \\
\text { growth, but high concentrations in } \\
\text { irrigation water reduce plant growth in } \\
\text { sensitive crops like wheat }\end{array}$ \\
\hline
\end{tabular}

Source: own research and Malakar et al. (2019).

pathogen. Most common symptoms are vomiting or diarrhoea (Tauxe, 2002; Bintsis, 2017). The most common pathogens are Escherichia coli bacteria, and Salmonella bacteria, Hepatitis A virus, amongst others. Heavy metals, such as iron, zinc and copper, are essential micronutrients in human diets. Other heavy metals, such as lead, mercury, cadmium and arsenic, are toxic, where the chemical form of these heavy metals influences the degree of toxicity (Jaishankar et al., 2014; Vázquez et al., 2015).

\section{Contamination Throughout the Food System}

Another point of attention in our analysis is the way contamination of food products can maintain throughout the different activities of the food system. For example, the quality of tilapia for consumption, can be affected by the poor quality of water used for growing, harvesting, transport and retail activities (Eltholth et al., 2015). In several countries in the world, however, consumers are already well-protected with regulation on food standards for consumer food products.

For several types of contaminants, the way the food is processed and prepared affects the severity of the contamination to human health. By cooking food, pathogens in the food are generally killed which prevents the consumer from foodborne infection. However, toxins produced by for example bacteria might remain in the food and, depending on the degree, can cause food intoxications (WHO, 2020). For several heavy metals, the preparation of the food affects the concentration of the heavy metal in the food. A study focussing on heavy mental contamination in seaweed described that the concentration of total arsenic decreased after soaking and cooking, although the inorganic form of arsenic, which is highly toxic, substantially increased after cooking (Banach et al., 2020).

\section{Methodology}

In the literature, many studies have published examples of the pollution of water resources at different points of the water system, but there are only a few examples of the impact of water pollution on the components of the food system. Particularly, there are hardly any studies that go beyond the impact of water quality on food production. With the Food System frame we link all relevant food system activities to the water quality of water resources. Moreover, we took the diets of consumers as the starting point, so that we considered a wide range of food products in the diets. Therefore, we reviewed the literature following the structure of the framework in Figure 2. The main purpose of using the framework is to identify how food security is affected by water quality in food system activities, and how water quality is affected by activities in the food system. When considering interventions for improving water quality the framework will identify the leverage point to reduce pollution within the food system and the framework will also identify urge and need to improve water quality issues of water resources available for the food system. It was not our aim to present an exhaustive list of examples, but to present examples for impacts of water quality on the food system and food security and vice versa, see Figure 2.

Our literature review consisted of two main parts. Firstly, we explored peer-reviewed articles from the Core Collection database of the Web of Science. We started with two combinations of search terms (i) "food security" and "water quality" (323 articles), (ii) "food system(s)" and "water quality" (93 articles). In both sets of articles, 19 articles were included in both sets, so that we were left with a set of 397 articles. We screened the titles and abstracts of this set on their relevance which publish an assessment of food products related to water 
TABLE 2 | Classification of the set of studies.

\begin{tabular}{|c|c|c|c|c|}
\hline \multirow[t]{2}{*}{ Classification of studies } & \multirow[t]{2}{*}{ All* } & \multicolumn{3}{|c|}{ Combination of "Water quality" with * } \\
\hline & & "Food security" & "Food system(s)" & "Both" \\
\hline Relevant case study linking water quality to food products & 12 & 11 & 0 & 1 \\
\hline Water management (pollution, quantity, reuse) & 86 & 80 & 4 & 2 \\
\hline Practices in agriculture, fisheries and aquaculture & 107 & 70 & 33 & 4 \\
\hline Nitrogen and phosphorus cycles & 48 & 16 & 29 & 3 \\
\hline Health & 16 & 11 & 2 & 3 \\
\hline Other subjects & 31 & 27 & 2 & 2 \\
\hline Irrelevant subjects & 97 & 89 & 4 & 4 \\
\hline Total & 397 & 304 & 74 & 19 \\
\hline
\end{tabular}

*The search in Web of Science was conducted on September 15, 2021.

TABLE 3 | Results of the combination of specific search terms.

\begin{tabular}{lc}
\hline Combinations of search terms & Number of articles* \\
\hline "Food quality" and "water quality" & 115 \\
"Food consumption" and "water quality" & 54 \\
"Food processing" and "water quality" & 48 \\
"Food security" and "WASH" & 42 \\
("Food system" or "food systems") and "WASH" & 21 \\
"Food preparation" and "water quality" & 18 \\
"Food storage" and "water quality" & 4 \\
\hline
\end{tabular}

*The search in Web of Science was conducted on September 15, 2021.

quality used test for impacts of water quality on food system activities see Table 2. This screening yielded 12 relevant case studies of impacts of water quality on food system activities. 86 articles dealt with water management subjects like monitoring of water pollution, water availability/scarcity and water monitoring of reuse. In 107 articles, the emphasis of the articles was on farming practices in agriculture, fisheries and aquaculture. The more general view on the nitrogen and phosphorus cycles were researched in 48 articles. In 16 articles, the main topic was health issues related to water quality, and in 31 articles, the main topic was another topic like climate policy or energy policy. In 97 articles, the topic turned out to be beyond the scope of food security or food system.

Based on 12 case studies, there is too little evidence for analysing all the relevant relationships of the framework in Figure 1. Except for one article published in 2005, the other 11 case studies articles were published in 2015 and later. However, we would have expected that there would have been older case studies in the literature.

Secondly, we identified three follow-up steps. The first step was to search the Core Collection of Web of Science with more specific search terms, see Table 3. Obviously, the sets of articles with the combined articles showed a large overlap as well as an overlap with the list in Table 2.
A second step was to search other databases for relevant case studies of impacts of water quality on food system activities from well-known organisations in the fields of water systems, International Water Management Institute (IWMI), agriculture and food, Food and Agriculture Organization (FAO) of the United Nations, and poverty and food security, The World Bank. These databases were reviewed based on the key words like water quality aspects, which yielded scientific reports and peerreviewed articles that did not show up in the scientific literature databases. The third step was to use the snow-balling approach by assessing of the references lists of the relevant articles. In this part of the search, the emphasis was on the water pollution types.

The gross set of articles in the second part was screened based on relevance and geographical location. Based on the resulting list, most studies found discussed the link between water quality and crop production. Furthermore, a relatively large number of studies presented pollution aspects of food production activities. In addition, we indicated the geographical locations of the studies based on low- and middle-income countries (LMICs). The relevant articles were incorporated in the description of the results in the next section.

\section{RESULTS}

This section presents the results of the literature review on the impacts of water quality on food security based on the framework presented in Figure 2. We structured the results according to the food system activities: food production, food processing, and food consumption. For each food system activity we discuss two directions of connection: first, the impact of water quality on the food system activity, and then the impact of the food system activity on water quality.

\section{Food Production \\ Water Quality Affecting Food Production}

Food production activities are largely divided into three activities: (i) crop production; (ii) livestock production and (iii) aquaculture and production. All three activities show different connections with water quality, which we will elaborate on below. 


\section{Crop Production}

In crop production, irrigation practices are used to overcome water shortages during crop growth or to increase crop productivity. Irrigation practices can rely on all water resources, such as surface water, ground water, wastewater, and water storages like rainwater harvesting.

Poor water quality for irrigation was due the natural occurrence of high heavy metal concentrations in ground and surface water sources. Furthermore, in several cases where surface and ground water were used for irrigation, the water quality was poor due to mainly heavy metal to pollution by nonfood activities upstream, such as mining industries. In the case of heavy metal pollution, there is an additional threat, because heavy metal residues accumulate in the soils, so pollution risks continue for a longer period. For all contaminants considered in this study, vegetables production is most often affected, and forms the highest risk for human health through consumption.

In LMICs water resources with high concentrations of nitrogen and phosphorus stimulate crop growth and thus increase crop productivity (Ensink et al., 2004). Irrigation of crops has a positive impact on food availability. However, if poor quality irrigation water is used, it might affect plant growth and crop quality (residues of contaminants in crops) and ultimately human health due to heavy metal, mycotoxins or cyanotoxins contamination or the presence of pathogens in crops. This has negative consequences for food security in multiple ways. Reduced crop production leads to lower food availability. Crops with contaminants residues lead to consumption of contaminated food products, which effects consumer's food safety (food utilization) and health. Obviously, the health consequences largely depend on the type and concentration of contaminants in the food products consumed. Poor quality irrigation water, regardless the water source, contributes to human health concerns (Bos et al., 2010). From a food security perspective, there is a trade-off between improving food availability by irrigating crops and accepting food safety risks with crop production (food utilization).

In crop production, wastewater has been used as a source of irrigation in water scarce countries (Siebe and Cifuentes, 1995). There are examples from LMICs in the continents of Africa, Asia and Latin America. In Jordan, reclaimed water represents a quarter of all water uses (Abu Qdais et al., 2019; Almanaseer et al., 2020). In Egypt and Tunisia, wastewater has been widely used in agroforestry projects and in anti-desertification efforts. In Central Mexico, municipal wastewater has long been used to irrigate crops (Siebe and Cifuentes, 1995), and in Keshopur and Okhla (India), large shares of crops on the local markets have been irrigated with treated or untreated wastewater (Amerasinghe et al., 2013). A similar case was found for potatoes and cauliflower production in Pakistan (Ensink et al., 2004). Thereby, since consumers are often unaware of health risks of consuming crops irrigated with wastewater, consumers prefer crops which are larger in size and look more fresh (Keraita and Drechsel, 2015).

From a microbiological perspective, groundwater is generally of good quality, wastewater is usually of poor quality, and the quality of surface water varies with the location (Steele and Odumeru, 2004).
Nitrogen and phosphorus pollution of water resources is one of the main issues around the world (McIntosh and Pontius, 2017; Walker, 2019). For crop growth, the presence of nitrogen and phosphorus in irrigation water can be beneficial, because it stimulates crop growth and thus crop productivity. One source with high concentrations of nitrogen and phosphorus is untreated wastewater. In Pakistan, wastewater was treated and discharged to farmers plots for a fee (Ensink et al., 2004). The use of wastewater for crop irrigation leads to a trade-off. On the one hand, irrigation increases crop productivity and foods availability of crops on local markets, which most likely increase the farmer's income (Amerasinghe et al., 2013; Damania et al., 2019). On the other hand, the use of wastewater might lead to several health risks for both the farmers and consumers. High nitrogen and phosphorus concentrations lead to algae blooming and possibly to cyanotoxins. In addition, pathogens and trace elements (heathy metals) might affect health on the short and/or long run.

Studies on pesticide contaminated water were reported frequently (FAO IWMI, 2018), although there were hardly any studies that examined the impact of contaminated irrigation water of the crop production and food safety for the consumers. In Saudi Arabia, for instance, pesticide residues were analysed but not found in irrigation water (Albedair and Alturiqi, 2020). There is a growing concern that in low-income countries without clear regulations and enforcement on pesticide use, farmers and consumers are unaware of the potential long-term, adverse health effects due to pesticide residue contamination of the daily consumption of locally produced fresh crops (FAO, 2016).

High concentrations of nitrogen and phosphorus in combination with warm temperatures can lead to a high presence of cyanobacteria in freshwater bodies. The cyanobacteria release cyanotoxins when these blue-green algae are blooming. If water with high concentration of cyanotoxins is used for irrigation, residues can accumulate in the crop, and those accumulated residues hamper plant growth (Malakar et al., 2019). As a result, the crop yield will be affected negatively. Moreover, these cyanotoxins can cause a wide range of human health effects when contaminated plants are consumed (Malakar et al., 2019). No specific case studies were found for the LMICs. In the case of mycotoxins, there were no case studies reported.

Irrigation with treated wastewater causes significant (negative) crop risk and consequently human health risks induced by pathogens (Steele and Odumeru, 2004). Several case studies on pathogens contaminated irrigation water showed mixed results on the impact of crops. In Ghana, the use of wastewater for irrigating fruit and vegetables leads to foodborne pathogens the food products supplied to urban markets (Amoah et al., 2006). In Israel, there were no pathogens found on cucumbers and melons, which where irrigated with potable water and treated wastewater (Obayomi et al., 2019).

Heavy metal polluted water used for irrigating crops was observed in Examples of irrigation water with high concentration of heavy metals in the proximity of industrial zones were reported for cultivation of cereals (mainly rice), horticulture, fodder crops, and aquaculture in India (Amerasinghe et al., 2013), and Bangladesh (Islam et al., 2018). The presence of heavy metal 
residues in wastewater is of higher concern in Asian counties compared to African countries (Amerasinghe et al., 2013). In West Africa, for instance, manufacturing industry is still limited compared to India (Amoah, 2011).

In India, China Pakistan and Saudi Arabia, wastewater with high concentrations of heavy metals used for irrigation led to residues in crops like rice, millet, vegetable crops and dairy via grass used as feed (Rattan et al., 2005; Khan et al., 2008; Mahmood and Malik, 2014; Balkhair and Ashraf, 2016). Risk assessments of the high concentration of heavy metals residues in India indicated that the highest concentration is found in vegetables (Sharma et al., 2006), although the consumption of those vegetables would not affect human health because they contribute less to the daily diet), than rice and wheat grains that have a smaller contamination but are major components of the daily diet (Rattan et al., 2005; Singh et al., 2010).

Arsenic contamination occurs naturally in arid and semiarid river basins, areas with volcanos and aquifers with alluvial sedimentary rock (Nordstrom, 2002) which affects irrigation water. The Eastern Gangetic Basin in Nepal, India and Bangladesh suffers from arsenic contamination of groundwater (Rajmohan and Prathapar, 2014), which exposure causes serious health issues. This arsenic-contaminated water was used for flood irrigation and as a consequence, arsenic accumulates in the soil and food grains, such as rice which is the staple food in the area (Rajmohan and Prathapar, 2014).

Furthermore, the use of irrigation water with high concentrations of heavy metals might lead to accumulation of heavy metal residues in the soil, which depends on the irrigation technique, the time of the season and the soil type. For example, an experimental study on the effects of the use of treated wastewater for rice production in the Algeria found evidence for the accumulations of residues in the soil for cadmium (Ca), Chromium (Cr), and iron (Fe) (Touil et al., 2020). Similar findings were reported for the application of wastewater for irrigation on Spain, Algeria (Martínez-Cortijo and Ruiz-Canales, 2018). Both studies concluded that it is not always clear to what extent (concentration levels as well as duration) reused wastewater contributes to the accumulation of heavy metals in the soil.

\section{Livestock}

In the 1980s, the FAO investigated the impact of water quality on livestock (Ayers and Westcot, 1985). Livestock uses water resources mainly for drinking. For livestock, the common toxicants included nitrogen, phosphorus, pathogens and heavy metals affect the health of animals and animal products. These may be directly toxic to the animal, cause the water to be unpalatable, or accumulate in the animal making its edible product (dairy, eggs, or meat) unsafe or unfit for human consumption (Ayers and Westcot, 1985). From a food security perspective, the production of animal-based food products was affected, which reduces food availability and food safety. Moreover, the quality of the food products was not guaranteed. The most hazardous or toxic water contaminants for the animals are nitrates (chemical composition of nitrogen), the heave metal iron (FE) and other chemical compounds such as fluoride and hydrogen sulphide. Animals usually can tolerate water with higher concentrations of contaminants than humans. When concentrations become too high, it can affect the animal's health and their productivity in terms of dairy, eggs and meat. Furthermore, it can affect lactation and reproduction as well. Therefore, it reduces food availability in the longer run as well. Toxicity problems are amplified when the forage used is also irrigated with the same potentially toxic water. The plants take up the salts, thus raising the toxicity risk to the animal when both the sources of feed and water combine to exceed the critical levels.

Drinking water with high nitrate levels may cause heavy growth of algae in watering points, which might lead to cyanotoxin pollution. In Africa, algae blooming and cyanotoxin pollution have been reported in lakes in many countries across the continent which are also used for drinking of livestock (Ndlela et al., 2016). Nevertheless, there were no studies for LMICs found that report a causal relationship between heavy algae growths and livestock deaths. In one third of the river basins of Africa, Asia and Latin America, sever pathogen pollution were found (UNEP, 2016). Many people on these continents are at risk as these rivers are sources for drinking water and other domestic activities. Moreover, one seventh of these river basins is used for fishing and fish production, so that the severe pathogen pollution affects the fish regeneration and fish production, which consequently affects people's food availability. Hot spots are the Nile river basin in Africa, the Ganges river basin in Asia (UNEP, 2016). For heavy metals, there were rare examples found. In India, the irrigation of grass with wastewater polluted with heavy metals did not have significant impact on the heavy metals concentration of milk (Singh et al., 2010).

\section{Fish and Seafood Production}

Next to the growing attention of fish in healthy diets, aquaculture is the fastest growing food sector (Willett et al., 2019). In Ghana, Bangladesh and Indonesia, for instance, approximately half of the animal protein in the meals per person is from fish (FAO, 2020). Of total fish production, the contribution of aquaculture constantly increased from 25.7 in 2000 to $46.0 \%$ in $2016-2018$. In China, followed by the rest of Asia aquaculture in absolute terms as well the share of total fish production is the highest (FAO, 2020). Despite, the contribution of aquaculture to total fish production remains minor in Africa, there is a fast increase in aquaculture over the last two decades (FAO, 2020).

For fish and seafood production, the main contaminants were nitrogen, phosphorus, pathogens and heavy metals. Pathogens can be transmitted to humans in the case of raw seafood, which affects food safety. Pesticide residues were found in fish in several case studies around the world, but there was no evidence for either reduced productivity of seafood or food safety due to the presence of pesticide residues in food products. However, high concentrations of nitrogen and phosphorus stimulate algae blooming, which might kill fish due to lack of oxygen or the formation of blue algae (cyanotoxins) and, hence, food availability is reduced. Heavy metal residues are found in fish and seafood products, but there is hardly any evidence that human health is a concern. 
Fish production can be affected by algae blooming. Fish farmers in the downstream areas of Bangkok in Thailand used herbicides to avoid algae blooms which could intoxicate their fish with cyanotoxins (Mrozik et al., 2019). However, neither exceedance of herbicide residues concentrations nor the presence of pathogens in shrimps were reported (Mrozik et al., 2019). In general, In the Nile delta in Egypt, pesticide residues were found in water and sediment samples, but the levels of pesticide residues in fish did not exceed the maximum residue limits (Shalaby et al., 2018). In Machakos and Kiambu counties in Kenya, several types of pesticide residues in fish reared in inland aquaculture were tested (Omwenga et al., 2016). Although pesticide residues were found in fish samples, the maximum levels of residues allowed were not exceeded. With severe pathogens pollutions in Africa and Asia, many rural communities rely on freshwater fish as a main source of protein in their diets, and their livelihood (UNEP, 2016). Pathogens polluted waters the negatively affect the regeneration and production of fish, which reduces food availability. Fish might be infected with pathogens and consumption of infected fish might lead to human health risks (UNEP, 2016), and reduce food safety. Although there are studies indicating that contact with severely polluted water by pathogens is threatening human health, we did not find studies reporting on how pathogens infected fish in LMICs. Other seafood like oysters, which are usually eaten raw, can also be polluted by pathogens which might lead to negative health effects. A study in the coastal waters of Myanmar found that urbanized coastal areas are likely a significant source of human pathogens and other contaminants, like polymers, found in oysters (Littman et al., 2020). Although fish contains essential micro-nutrients, fish high in the food chain (high trophic level) might contain high concentrations of mercury (Willett et al., 2019) due to the presence of mercury in open water bodies. In Africa, heavy metal pollution caused by mining activities and unsustainable agricultural practices affected fish in several cases (Yabe et al., 2010). Seaweed is seen as an alternative for animal proteins to be used for animal feed and food for humans (FAO, 2020). Elements present in the environment are accumulate in seaweeds. This can be all different type of pollutants, such as pathogens like Salmonella, arsenic, cadmium, residuals of pesticides.

\section{Food Production Affecting Water Quality}

Crop production, livestock production and aquaculture production all contribute to water pollution (UNEP, 2016), although the type of contamination differs across food production types. In crop production, it is mainly due to unsustainable farming practices like overuse of organic and chemical fertilizer, and over use of pesticides including herbicides. It leads to leaching of nitrogen, phosphorus and pesticide residues to the soil and to runoff into surface waters. Nitrogen and phosphorus contamination of surface waters is also observed in areas with intensive livestock production due to unsustainable management of manure of livestock. These areas also show contamination of pathogens. For inland aquaculture, herbicides are used to prevent algae blooming in ponds, and pesticides are used for pest control. Indirectly, pesticide and herbicide residues contribute to heavy metal pollution because heavy metals are, generally, components of those pesticide and herbicide products.

\section{Crop Production}

The intensification of crop production systems resulted in an increase in fertilizers and water use, affects water quality in several ways. Intensive use of fertilizers led to a substantial amount of leaches into water or the air (Damania et al., 2019). In India, the growth in food production in the mid-1960s rapidly increased agricultural production and food security, but it was accompanied with a rise in the use of synthetic fertilizers such as nitrogen, phosphorus and potassium. As a result, the runoff to surface waters of these substances increased as well, which increased the concentrations of nitrate and nitrite in rivers in India (Damania et al., 2019). In Vietnam for instance, the imports of mineral fertilizers grew with more than 70\% between 1995 and 2004 (Sebesvari et al., 2012). Misuse of fertilizers frequently led to runoff or leaching to surface water or ground water (Hach and Tan, 2007; Damania et al., 2019; Almasri et al., 2020). On field level overuse of fertilizer application might have a negative impact on crop yield, for example in rice production the overapplication of nitrogen may lead to more insect pests (Lu et al., 2004) which might lead to decreasing yields or to higher use of pesticides to control the pest. Pesticide use has increased globally, and the runoff from treated plants to soil and water resources is widespread (FAO IWMI, 2018, p. 82). Between 2004 and 2013, pesticide emissions increased by almost $30 \%$ with the main hotspot in Central China and affected surface water quality (Sun et al., 2019). In Taiwan, the sales of glyphosate increased with more than 70\% between 2007 and 2016 (Tsai, 2019). Pesticides might contain heavy metals, like lead and copper for instance, so that over-use of pesticides does also lead to heavy metal pollution of soul and water sources (FAO IWMI, 2018, p. 87).

\section{Livestock}

Livestock excreta contain considerable quantities of nitrogen and phosphorus, oxygen depleting substances and pathogens and, in intensive livestock systems, also heavy metals, drug residues, hormones and antibiotics (FAO IMWI, 2017, p. 10).

Manure of livestock is a major source of nitrogen and phosphorus required for soil fertilization. However, over-use of fertilizers causes pollution in soil and water resources, the severity of pollution depends on the geographical location. Livestock production accounted for $73 \%$ of the total nitrogen and phosphorus pollution from agriculture (Leip et al., 2015). In South, East and Southeast Asia, contamination from manure is a growing issue, in these parts of the world a fifth of the cropland contains an overload of phosphorus, manure from livestock is the major contributor (Otte et al., 2019). However not in all parts of the world nitrogen and phosphorus contamination is an issue. In around $80 \%$ of the African countries there is a nitrogen shortage instead of a nitrogen surplus (Otte et al., 2019), and irrigation water with high(er) concentrations of nitrogen from manure might be an advantage for improved crop productivity. From a health perspective, manure from livestock is also a source of pathogens in water (Hubbard et al., 2004). 
Manure can contaminate water sources with pathogens like Escherichia coli. As earlier described, if contaminated water is used to irrigate crops, like vegetables, the crop can be a source of pathogens and might infect consumers (Kirby et al., 2003).

\section{Fish and Seafood Production}

In intensive aquaculture next to feed, pesticides, herbicides and fertilizers are used (Mrozik et al., 2019). For example, in the production of tilapia and shrimp in Thailand, fertilizers are used during the pond preparation to stimulate photosynthetic production. However, as mentioned before, herbicides are used to prevent algae blooming caused by the high concentration of nitrogen and phosphorus. In addition, pesticides are used to reduce the disease pressure in fish and seafood. Cases are known where residuals of these inputs are present in the wastewater of aquatic production systems. In Bosnia and Herzegovina, heavy metals like cadmium $(\mathrm{Cd})$, mercury $(\mathrm{Hg})$, and lead $(\mathrm{Pb})$ were found in fish and sea products as well as in human consuming these food products (Djedjibegovic et al., 2020). Other examples like in South Africa were reported (Bosch et al., 2016).

\section{Food Processing Industry}

In food processing, water is used for boiling or steaming, for transport of food products during processing, and cleaning of food products and food processing equipment. Good water quality is required for these activities. In the literature, the main concern found was contamination of food processed with pathogens. Note that food products contaminated with heavy metal residues in earlier stages of the food system, might remain contaminated during food processing. The main impact on food security is the negative impact on food safety. Food processing activities contribute to pollution of water resources through wastewater discharge. In the literature, there were found examples of nitrogen, phosphorus, pathogens and heavy metal contaminants.

\section{Water Quality Affecting Food Processing}

In food processing, water is used for several purposes, like for thermal transfer median (boiling or steaming of food products), for transport of food products during processing and for cleaning of food products and food processing equipment (Kirby et al., 2003). Each water-related step in food processing has its own requirement for the quality of water. There are two ways that water contamination occurs during food processing. Firstly, the incoming water can be contaminated, and secondly water can be contaminated during the food processing (Kirby et al., 2003). In the latter case, water can be contaminated by an unhygienic factory environment or by cross-contamination which occurs when contaminated products pollute other products via the (re)used water (Jawahar and Ringler, 2009; Holvoet et al., 2012).

Cross-contamination in water can take place when water is reused. A case in two Belgian companies which produce fresh-cut vegetable showed that when the water for washing the vegetables were not changed often enough resulted in the accumulation of microorganisms, so contamination of the processed vegetables increased instead of decreased during washing (Holvoet et al., 2012). Next to accumulation of the contaminates within a food processing step, water used for different processes in the production increase the chance of cross-contamination (Jawahar and Ringler, 2009).

The use of water with high concentrations of pathogens in food processing activities can lead to health risks. In a study for Ouagadougou, Burkina Faso, the effect of washing lettuce on microbial load with irrigation water and with tap water was compared. Washing lettuce with tap water reduced the microbial load if the water is changed more often (Dao et al., 2018). We found a few cases with contaminated water being used as main ingredient of the processed food. These studies were examples of more informal food processing like food preparation at street markets for instance. On street markets in Jakarta, Indonesia, edible ice, prepared with water of poor quality, was sold. The processed ice products contained several types of cholera bacteria, including serogroups which are resistant to multiple antibiotics and might cause a potential cholera epidemic (Waturangi et al., 2013). In an earlier study in Semarang, Indonesia (Gasem et al., 2001), a positive correlation between the consumption of ice and an infection disease was reported. In that case, ice cubes contained with typhoid fever were bought from street vendors. Street vendors sold ice which they purchased from factories that produce ice for fish storage and transport but not meant for human consumption. For several outbreaks of food borne diseases caused by food processing, infected workers were the source (Kirby et al., 2003). To avoid faecal-oral diseases personal hygiene is crucial to avoid these food-borne diseases. Although this has not a direct link with the quality of the water used during food processing, the access to enough safe water for personal hygiene plays a crucial role in food safety.

\section{Food Processing on Water Quality}

There are many ways in which food processing affects water quality and depends on the produced food product, the process and the used equipment. Depending on the type of processed food, high concentrations of organic content is a common factor Valta et al., 2015). The presence of sewage systems and the legislation on treatment and wastewater discharge in place, largely determine to what extent wastewater from food processing activities leads to water pollution. In addition, depending on the type and concentration of contaminant as well as the capacity of the treatment plant, contaminants might end in the environment. In 1997 in France, 53\% of the phosphorus collected in water treatment plans came from the food processing industries. Of this influx, a significant amount will not be removed by the treatment plants, so will affect the water quality of the water bodies to which the treated wastewater is discharged. Among other contaminants, a substantial part of the phosphorus is from used chemical to cleaning products, surfaces and instruments (Tusseau-Vuillemin, 2001). Wastewater from animal food processing industries, like slaughterhouse, might lead to water pollution of nitrogen and phosphorus as well pathogens. In Nigeria, untreated wastewater polluted the Ikpoba River with pathogens. Despite self-purification of the river, high concentrations were found 400 meter downstream from the discharge location (Benka-Coker and Ojior, 1995). Although we did not find a study for food processing, the use of aging and 
corroding pipes and pipe fittings might cause wastewater from food processing containing heavy metals like lead, aluminium, copper, cadmium, and zinc.

\section{Food Consumption}

In the case of food consumption, we distinguished water for drinking water and water for food preparation (including street food). In most cases, pollution of drinking water is caused by either the use of contaminated water sources (surface water, ground water or wastewater), or the poor quality of water distribution infrastructure. A few examples in the literature present contamination of street food due to the use of unsafe water resources for food preparation. Nitrogen, phosphorus, pathogens, and heavy metals contaminations of water resources affected food consumption.

Food consumption contributes to water pollution through wastewater discharges. In countries with sophisticated sewage systems, wastewater is treated before it is reused or discharged to surface waters. Nitrogen and phosphorus contamination and pathogens are associated with human excretion, which is associated to food consumption. The more food is consumed, the more human excretion will be produced, and most likely water resources will be more polluted by wastewater discharges, although densely populated areas are more suitable for proper sewage systems and wastewater treatment facilities.

\section{Impact of Water Quality on Food Consumption}

In food consumption, there are two ways that water is used: water used for preparing meals and for drinking water. The preparation of meals can take place at home or outside the home (e.g., restaurants, street vendors or take away food). We can illustrate these with a study in Cameroon, in which insufficient amounts of drinking water and water for food preparation affected households' food security which showed-up in multiple ways (Nounkeu and Dharod, 2020). Firstly, household members chose to drink smaller amounts of water to save drinking water for the next days. Secondly, during the dry season, poor quality drinking water was used due to the lack of good water. Thirdly, there was insufficient fuel wood for water boiling to improve quality before consumption. Thus, part of the water was boiled which was provided to infants. Fourthly, food consumption was affected by the access to proper water for cooking and meal preparation. Interviewees mentioned that the amount of available water affected the ingredients used for the meal or even stated they went to bed hungry because there was no water. Below, we first discuss drinking water activities and then we discuss water used for preparing meals for which we emphasise the role of street food.

\section{Drinking Water}

Drinking water quality can be affected in multiple ways and by various pollutants. In 2015, 844 million people around the world did not have access to basic drinking water service, which means that they have to rely on water abstracted directly from surface water, unprotected wells and springs (WHO, 2017). Water used for drinking, sanitation and for food preparation can be polluted by zoonotic pathogens due to manure from livestock polluted the water source, especially in backyard livestock keeping, and human pathogens due to the lack of affective sanitation upstream. Evidence from Ghana and Bangladesh showed that households with five or more numbers of large animals, like cattle, goats and sheep, and with eight or more small animals, like poultry, were associated with drinking water contaminated by pathogens (Wardrop et al., 2018).

Other cases are known were high concentrations of nitrate in ground water, used for drinking water, led to methemoglobinemia by bottle-fed infants (Kirby et al., 2003). High concentrations of contamination in irrigation canals and field outflows have been reported for both the Red River Delta and the Mekong River Delta in Vietnam (Sebesvari et al., 2012; Toan et al., 2013; Chau et al., 2015). The frequent detection of pesticides in rural areas was a threat to human health as surface water is often used in rural areas for drinking water and irrigation (Sebesvari et al., 2012; Toan et al., 2013). The treatment normally used by rural households to prepare surface water prior to consumption (flocculation followed by boiling) is insufficient for the removal of the studied pesticides and boiling can actually increase the concentration of non-volatile pollutants (Toan et al., 2013). Even in cases of harvested rainwater or purchased bottled water, up to 12 different pesticides have been detected at concentrations exceeding the European Commission's parametric guideline values for both individual and total pesticides in drinking water (Chau et al., 2015). For other organic contaminants, there is little knowledge on the potential health impacts of steroids, pharmaceuticals and nanoparticles in drinking water (Damania et al., 2019).

Safe drinking water should be free from pathogens (WHO, 2017). The presence of pathogens in drinking water could cause serious illnesses such as respiratory and skin diseases (Ashbolt, 2015). In countries like The Netherlands, France and Germany, for instance, there are regular monitoring activities for the presence of legionella in drinking water (Ashbolt, 2015). Results of real-world case studies on accidental contamination of water systems with Escherichia coli and Salmonella contamination showed that the causes of contamination are due to the tap water infrastructure and flushing and chlorination can help return a water system to service (Szabo and Minamyer, 2014). In South Africa, mycotoxins were found in tap water used for drinking, but the tested samples of water indicated that the tolerable daily intake of the mycotoxins were not exceeded (Mhlongo et al., 2020).

Globally, drinking water can be polluted by trace elements from different sources such as from industries when for example surface water is used for drinking water (Sharma and Bhattacharya, 2017). In addition, naturally present geogenic elements might contaminate groundwater resources, as described, in the previous chapter, and might affect millions of people if these water sources are used for drinking water. Around 200 million people in 25 counties are affected by fluoride exposure, while in Bangladesh, amongst other countries, 20 million people are long-term exposed by arsenic via drinking water. In several parts of the world mining activities polluted water resources used for drinking water. For example, mining activities in Chile polluted water resources by arsenic results 
in that still more than 800,000 Chileans are exposed by arsenic polluted drinking water. Depending on the material of the pipes, drinking water can be contaminated by heavy metals like lead, copper or aluminium due to corroding of the pipes (Damania et al., 2019).

In Egypt, the main drinking water resource is the Nile river, which suffers from heavy metal pollution due to wastewater discharges from manufacturing industries, agricultural activities and domestic water use (Abdel-Satar et al., 2017). The heavy metal contamination of the Nile endangers human health through consumption of drinking water.

\section{Street Food}

In many parts of the world food consumption out of home, street food, contains a substantial amount of total food consumption. In particular in developing countries, street food contributes substantially to nutrition and food security (Omemu and Aderoju, 2008; Barker et al., 2014; Alimi, 2016) and, for example in Nigeria, street food might be cheaper than cooking at home (Omemu and Aderoju, 2008). In addition, street food might contain non-traditional ingredients not cooked at home, like lettuce a common ingredient in street food dishes in Accra, Ghana (Barker et al., 2014). Despite the access to nutritious food, food safety issues are common and is associated with significant health risks (Alimi, 2016), at which the access to save water plays a crucial role. Poor water quality mainly has indirect effects on street food and, in the end, the consumer and is mainly caused by the lack of access to sufficient amounts of (potable) water, which results in insufficient hygiene to avoid food borne diseases (Barro et al., 2006; Omemu and Aderoju, 2008). In a case from Nigeria, hands of the street food venters were not properly washed due to the lack of clean tap water, and ingredients were not (sufficiently) washed before food preparation (Omemu and Aderoju, 2008). In a case from Burkina Faso, dish washing water was contaminated with pathogens because it was not (frequently) refreshed (Barro et al., 2006).

\section{Impact of Food Consumption on Water Quality}

As discussed earlier for clean water, the access to proper sanitation is also a major health issue in many parts of the world. In $2015,39 \%$ of the world population had access to safely managed sanitation, while 892 million people, $12 \%$ of the world population, practised open defecation (WHO, 2017). The access to proper sanitation and the treatment of wastewater with human waste affects the food systems in several ways. Without proper sanitation and treatment of sewage, human waste (faeces and urine), which contains nitrogen, phosphorus and pathogens, is discharged to surface water and contributes to the decrease of water quality.

Over the last decades, the share of nitrogen and phosphorus from human waste recycled in agriculture has strongly decreased in urban areas. In 2007, around 20 and $70 \%$ of the nitrogen and phosphorus from, respectively, urban and rural human waste were recycled (Liu et al., 2008). A significant share of nitrogen and phosphorus that is not recycled in agriculture will end-up in the water system and might eventually pollute coastal waters (Amin et al., 2017). Urbanization is a continues process with diets shifting toward more animal-based protein consumption, which leads to higher concentrations of nitrogen and phosphorus in human waste that, in turn, further increases nitrogen and phosphorus pollution of water bodies in urbanized areas. However, this is not only a (growing) issue in LMICs with limited water treatment facilities, because the majority of the treatment facilities in high-income countries cannot remove nitrogen and phosphorus from wastewater (Mihelcic et al., 2011).

The lack of access to safe sanitation, including effectively treating human waste, leads to a higher probability of faecaloral transmission in which pathogens can be transferred through hands, soil, insects and water (Cumming and Cairncross, 2016). To prevent faecal pathogen contamination to food access to clean water is a crucial aspect. In India, half of population defecates in the open (Spears et al., 2013), which directly contributes to the pollution of surface waters by pathogens, nitrogen and phosphorus, although it is unclear to what extent (Amin et al., 2017). To meet the goal toward improved sanitation, pit latrines are the most basic and less expensive form which results in that these common sanitation form will rise (Graham and Polizzotto, 2013). However, pit latrines can impact the water quality of ground water and might have a negative impact on human health when groundwater is used for drinking water. The degree of faecal pathogen contamination from latrines to groundwater pollution depends on the distance to the latrine (Dzwairo et al., 2006; Graham and Polizzotto, 2013; Ravenscroft et al., 2017). Although the use of pit latrines near groundwater used for drinking water is increasing, limited studies are conducted on groundwater pollution from pit latrines. Available studies frequently found groundwater pollution by latrines (Graham and Polizzotto, 2013). In a study in Bangladesh, nearfield ground waters were more frequently and more intensely polluted with faecal contamination than far-field groundwaters (Ravenscroft et al., 2017).

\section{DISCUSSION}

\section{Food Security and Water Quality}

Except for nitrogen and phosphorus, the use of contaminated water in the food system leads to negative consequences for food security. Table 4 summarizes of the impact of several water contaminants on food chain activities based upon on the examples we found in the literature and described in Results section. For LMICs, we did not find examples for all relationships between contaminants and food system activities, although the literature indicated that several LMICs did suffer from contaminations of their water resources. The absence of examples in our review does not mean that these examples do not exist.

In addition, the impact on food security is also summarized. In food system activities in LMICs, contaminated water is often used due to the scarcity of uncontaminated alternative water resources. Although contamination is usually considered a negative phenomenon, this is not always the case. In nitrogen-poor and phosphorus-poor countries, nitrogen- and phosphorus-rich water resources might have a positive impact on crop production. However, nitrogen- and phosphorus-rich 
TABLE 4 | Impacts of water contaminants on food system activities.

\begin{tabular}{|c|c|c|c|c|c|}
\hline \multirow[t]{3}{*}{ Water contaminants } & \multicolumn{5}{|c|}{ Affected food system activities } \\
\hline & \multicolumn{3}{|l|}{ Agriculture } & \multirow[t]{2}{*}{ Food processing } & \multirow[t]{2}{*}{ Food consumption } \\
\hline & Crop production & Livestock & Fish and seafood & & \\
\hline Fertilizer & Positive & Negative, indirectly & Negative, indirectly & Not found & Negative \\
\hline Pesticides & Not found & Not found & Not found & Not found & Not found \\
\hline Cyanotoxins & Negative & Negative & Negative & Not found & Negative \\
\hline Pathogens & Negative & Not found & Negative & Negative & Negative \\
\hline Heavy metals & Negative & Not found & Negative & Not found & Negative \\
\hline
\end{tabular}

TABLE 5 | Impacts of water contaminants on food security and aspects of food availability, food affordability and food utilization.

\begin{tabular}{|c|c|c|c|c|}
\hline \multirow[t]{2}{*}{ Water contaminants } & \multicolumn{3}{|c|}{ Food security } & \multirow[b]{2}{*}{ Overall } \\
\hline & Food availability & Food accessibility & Food utilization & \\
\hline Fertilizer & $\begin{array}{l}\text { Positive for crop production in areas } \\
\text { with poor soil quality }\end{array}$ & $\begin{array}{l}\text { Positive as a result of increasing food } \\
\text { availability }\end{array}$ & & Positive \\
\hline Pesticides & & & $\begin{array}{l}\text { Negative due to pesticides in crop } \\
\text { production and aquaculture }\end{array}$ & Negative \\
\hline Cyanotoxins & $\begin{array}{l}\text { Negative for crops (reduced growth), } \\
\text { livestock (health) and (fish) }\end{array}$ & Negative & Negative for crops & Negative \\
\hline Pathogens & & & Negative crops and seafood & Negative \\
\hline Heavy metals & $\begin{array}{l}\text { Negative for fresh produce crops from } \\
\text { contaminated water use for amount }\end{array}$ & $\begin{array}{l}\text { Negative for fresh produced crops } \\
\text { due to higher food availability }\end{array}$ & Negative crops and seafood & Negative \\
\hline
\end{tabular}

TABLE 6 | Impacts of food system activities to pollution of water resources.

\begin{tabular}{|c|c|c|c|c|c|}
\hline Activities & Nitrogen and phosphorus & Pesticides & Cyanotoxins & Pathogens & Heavy metals \\
\hline Crop production & Yes & Yes & $\begin{array}{l}\text { Indirectly through nitrogen } \\
\text { and phosphorus pollution }\end{array}$ & Not found & $\begin{array}{l}\text { Yes through pesticide } \\
\text { pollution }\end{array}$ \\
\hline Livestock & Yes & Yes & Indirectly & Yes & Yes \\
\hline Aquaculture & Yes & Yes & Indirectly & Yes & Yes \\
\hline Food processing & $\begin{array}{l}\text { Yes through untreated } \\
\text { discharges }\end{array}$ & Not found & Indirectly & $\begin{array}{l}\text { Yes through untreated } \\
\text { discharges }\end{array}$ & $\begin{array}{l}\text { Yes through untreated } \\
\text { discharges }\end{array}$ \\
\hline Food consumption & $\begin{array}{l}\text { Yes through untreated } \\
\text { discharges }\end{array}$ & Not found & Indirectly & $\begin{array}{l}\text { Yes through untreated } \\
\text { discharges }\end{array}$ & $\begin{array}{l}\text { Yes through untreated } \\
\text { discharges }\end{array}$ \\
\hline
\end{tabular}

surface waters are prone to algae blooming, which might lead to cyanotoxins contamination of the water under certain climate conditions.

Based on the results in Table 4, the impact of water resources on food security can be elaborated on, see Table 5. The results show that there are dilemmas emerging within the food system. The EAT-Lancet healthy diets promote the consumption of seafood and vegetables from a nutritional perspective. However, these food items are most prone to cause human health issues if contaminated water is used in the food system activities. In crop production, water resources are used for irrigation to maintain or increase crop productivity and, consequently, food availability. However, when irrigation water is contaminated with pathogens or heavy metals, there are negative impact on food safety (food utilization). The overall impact of the use of polluted irrigation water on food security is ambiguous. These dilemmas emerge in the case of food products like fish, shell fish and vegetables produced in LMICs where food safety standards are often lacking.
These dilemmas depend on the context. In India, there are more areas of industrialisation which contribute to heavy metal contamination of rivers and wastewater discharges than in Africa, where are large industrial areas are less plentiful. Therefore, in African countries the use of untreated wastewater for irrigation might cause less water quality issues although this depends on the cultivated crops, the way these crops are prepared for meals, and to what extent wastewater streams are controlled (which is often not the case in Africa).

The list of water contaminants included in this study was not exhaustive. In the future, the list of water contaminants could be expanded with antibiotics and nanoparticles for instance.

\section{Food System and Water Discharges}

All activities of the food system contribute to discharges of contaminants to water resources, see Table 6. In food production, unsustainable farming practices cause pollution of water resources with nitrogen, phosphorus, pesticides, heavy 
metals and pathogens due to the overuse of fertilizers and pesticides in crop production and aquaculture, and manure management of livestock. In most cases of food production, the pollution sources are diffuse. In food processing, water is used mainly for cleaning food products, and cleaning food processing equipment, and wastewater is discharged (point pollution). In LMICs, these companies are often not connected to a sewage system, and wastewater is indirectly discharged to surface waters or used for other services like irrigation. Food consumption is an activity for all humans around the globe and human excretion is a main source of wastewater potentially with contaminants. However, from human excretion, it is hard to distinguish the contribution of food products, so that it is also hard to propose changes in diets when this relationship is unknown. A first logical step would be to make sure that human excretion is collected, and wastewater is treated, which is not common around the world. A second step could be to determine the characterisation of human excretion in wastewater and how it relates to human diets in areas around the world. As for food processing, the connection to sewage systems of houses is crucial to control for wastewater treatment and pollution.

\section{Contamination Throughout the Food System}

Food contaminated with poor quality irrigation water can be prolonged throughout the succeeding food system activities. Fresh leafy vegetables irrigated with untreated irrigation water might be contaminated with pathogens or heavy metals, and when these vegetables are supplied to the local market, they are still a threat to food security and human health. When vegetables with pathogen contamination are boiled, these pathogens are likely to be removed and human health is unlikely to be affected. In contrast, when food with heavy metals contamination is boiled, contamination will remain. Whether water can safely be used along specific food system activities is context-dependent, thus depending on what kind of food is produced, how the food is processed and how it is prepared at the consumers' home. Or the other way around, whether the effects of food system activities on the water quality become an issue depends on how water is further used in the water system (including coastal areas) and how the contaminates might accumulate in the system. Food safety is a crucial component to achieve food security with healthy diets as goal. To accomplish this goal, people should have access to enough safe water, and proper sanitation, which is still lacking for many people in LMICs.

\section{WASH as a Key Element to Achieve Food Security}

Based on our literature review, there seems to be a missing link in research between water, sanitation and hygiene (WASH) and food systems. With the combination of keywords "WASH" and "food systems," we did not find any article that discussed impact of water quality on food security. Tap water is an essential part of the food system (i.e., food consumption), as it is one of the essential component within a healthy diet next to carbohydrates, proteins and many other micro and macro nutrients (Jéquier and Constant, 2010). Moreover, the access to water of sufficient quality indirectly influences the hygienic conditions during food processing and food preparation. There are studies that investigated the relation between WASH and children's health. WASH can result in stunting, the impaired growth and development that children experience from poor nutrition, repeated infection, and inadequate psychosocial stimulation (Cumming and Cairncross, 2016), and childhood undernutrition. Increasing the amount of pit latrines and increasing the amount of boreholes for drinking water nearby lead to water pollution by latrines which affects drinking water quality (Graham and Polizzotto, 2013), where children but also adults are affected. By acknowledging that WASH, food systems and water management are highly interrelated for all people, the interconnections should not be analysed in isolation. To improve human nutritional status, it is essential to consider human health, the food system and the water system simultaneously; the complex interactions should be understood and trade-offs which will appear during policy making need to be identified and weighed.

Although this study focused on the interactions between water quality and food systems, many hygienic issues, such as improper hand-washing before food preparation/processing, are not directly related to the water intake by humans but relevant aspects in the food systems, as indicated before with the importance to consider WASH in food systems as well. These issues emerge often in areas where there is lack of clean water.

\section{DATA AVAILABILITY STATEMENT}

The original contributions presented in the study are included in the article/supplementary material, further inquiries can be directed to the corresponding author.

\section{AUTHOR CONTRIBUTIONS}

VL, TL, and SR designed the problem. TL and VL wrote the manuscript. VL prepared the figure. SR reviewed the manuscript. All authors contributed to the article and approved the submitted version.

\section{FUNDING}

This research was carried out as part of the Knowledge Base program Food Security and Valuing Water of Wageningen University and Research and it was subsidized by the Dutch Ministry of Agriculture, Nature and Food Quality.

\section{ACKNOWLEDGMENTS}

This is to acknowledge the contributions of specific colleagues, institutions, or agencies that aided the efforts of the authors. 


\section{REFERENCES}

Abdel-Satar, A. M., Ali, M., and Goher, M. E. (2017). Indices of water quality and metal pollution of Nile River, Egypt. Egypt. J. Aquat. Res. 43, 21-29. doi: 10.1016/j.ejar.2016.12.006

Abu Qdais, H., Abdulla, F., and Kurbatova, A. (2019). Wastewater reuse in Jordan and its potential as an adaptation measure to climate change. J. Environ. Eng. Sci. 14, 203-211. doi: 10.1680/jenes.19.00029

Al Evans E. V., Mateo-Sagasta, J., Qadir, M., Boelee, E., and Ippolito, A. (2019). Agricultural water pollution: key knowledge gaps and research needs. Curr. Opin. Environ. Sustain. 36, 20-27. doi: 10.1016/j.cosust.2018.10.003

Albedair, L. A., and Alturiqi, A. S. (2020). Evaluation of pesticide residues in the irrigation water, soil and assessment of their health risks in vegetables from sub-urban areas around Riyadh District, Saudi Arabia. Environ. For. 22, 1-12. doi: 10.1080/15275922.2020.1805826

Alimi, B. A. (2016). Risk factors in street food practices in developing countries: a review. Food Sci. Human Wellness 5, 141-148. doi: 10.1016/j.fshw.2016. 05.001

Almanaseer, N., Hindiyeh, M., and Al-Assaf, R. (2020). Hydrological and Environmental Impact of Wastewater Treatment and Reuse on Zarqa River Basin in Jordan'. Environments 7:14. doi: 10.3390/environments7020014

Almasri, M. N., Judeh, T. G., and Shadeed, S. M. (2020). Identification of the nitrogen sources in the Eocene Aquifer Area (Palestine). Water 12:1121. doi: 10.3390/w12041121

Amerasinghe, P., Bhardwaj, R. M., Scott, C., and Jella, K. (2013). Urban Wastewater and Agricultural Reuse Challenges in India. IWMI research report 147. IWMI Research Report. Colombo, Sri Lanka: International Water Management Institute (IWMI). doi: 10.5337/2013.200

Amin, N., Kroeze, C., and Strokal, M. (2017). Human waste: an underestimated source of nutrient pollution in coastal seas of Bangladesh, India and Pakistan. Mar. Pollut. Bull. 118, 131-140. doi: 10.1016/j.marpolbul.2017.02.045

Amoah, P. (2011). Low-Cost Options for Reducing Consumer Health Risks from Farm to Fork Where Crops Are Irrigated with Polluted Water in West Africa. Colombo: IWMI.

Amoah, P., Drechsel, P., Abaidoo, R. C., and Ntow, W. J. (2006). Pesticide and Pathogen Contamination of Vegetables in Ghana's Urban Markets. Arch. Environ. Contam. Toxicol. 50, 1-6. doi: 10.1007/s00244-004-0054-8

Ashbolt, N. J. (2015). Microbial contamination of drinking water and human health from community water systems. Curr. Environ. Health Rep. 2, 95-106. doi: 10.1007/s40572-014-0037-5

Ayers, R. S., and Westcot, D. W. (1985). Water Quality for Agriculture. FAO Irrigation and Drainage Paper 29, rev. 1. Rome: Food and Agriculture Organization of the United Nations. Available online at: http://www.fao.org/ 3/t0234e/T0234E00.htm\#TOC (accessed December 19, 2020).

Balkhair, K. S., and Ashraf, M. A. (2016). Field accumulation risks of heavy metals in soil and vegetable crop irrigated with sewage water in Western Region of Saudi Arabia. Saudi J. Biol. Sci. 23, S32-44. doi: 10.1016/j.sjbs.2015.09.023

Banach, J. L., Hoek-van den Hil, E. F., and Fels-Klerx, H. J. (2020). Food safety hazards in the European seaweed chain. Comprehen. Rev. Food Sci. Food Saf. 19, 332-364. doi: 10.1111/1541-4337.12523

Barker, S., Amoah, P., and Drechsel, P. (2014). A probabilistic model of gastroenteritis risks associated with consumption of street food salads in Kumasi, Ghana: evaluation of methods to estimate pathogen dose from water, produce or food quality. Sci. Total Environ. 487, 130-142. doi: 10.1016/j.scitotenv.2014.03.108

Barro, N., Bello, R. A., Itsiembou, Y., Savadogo, A., Cheik Amado, O.C., and de Souza Comlan, T. A. (2006). 'Street-Vended Foods Improvement: Contamination Mechanisms and Application of Food Safety Objective Strategy : Critical Review'. Pakistan Journal of Nutrition 6 (1): 1-10. doi: $10.3923 /$ pjn.2007.1.10

Benka-Coker, M. O., and Ojior, O. O. (1995). Effect of slaughterhouse wastes on the water quality of Ikpoba River, Nigeria. Bioresour. Technol. 52, 5-12. doi: 10.1016/0960-8524(94)00139-R

Bintsis, T. (2017). Foodborne pathogens. AIMS Microbiol. 3, 529-563. doi: 10.3934/microbiol.2017.3.529

Bos, R., Carr, R., and Keraita, B. (2010). "Assessing and mitigating wastewaterrelated health risks in low-income countries: an introduction," in Wastewater Irrigation and Health: Assessing and Mitigating Risk in Low-Income Countries, eds. P. Drechsel, C. A. Scott, L. Rashid-Sally, M. Redwood, A. Bahri (Colombo, Sri Lanka: International Water Management Institute), 29-47. Available online at: https://publications.iwmi.org/pdf/H042602.pdf (accessed December 19, 2020).

Bosch, A. C., O’Neill, B., Sigge, G. O., Kerwath, S. E., and Hoffman, L. C. (2016). Heavy metals in marine fish meat and consumer health: a review: heavy metals in marine fish meat. J. Sci. Food Agric. 96, 32-48. doi: 10.1002/ jsfa. 7360

Chau, N. D. G., Sebesvari, Z., Amelung, W., and Renaud, F. G. (2015). Pesticide pollution of multiple drinking water sources in the Mekong Delta, Vietnam: evidence from two provinces. Environ. Sci. Pollut. Res. Int. 22, 9042-9058. doi: 10.1007/s11356-014-4034-x

Chigor, V. N., Umoh, V. J., Okuofu, C. A., Ameh, J. B., Igbinosa, E. O., and Okoh, A. I. (2012). Water quality assessment: surface water sources used for drinking and irrigation in Zaria, Nigeria are a public health hazard. Environ. Monitor. Assess. 184, 3389-3400. doi: 10.1007/s10661-011-2396-9

Cumming, O., and Cairncross, S. (2016). Can water, sanitation and hygiene help eliminate stunting? current evidence and policy implications: water, sanitation and hygiene, and stunting. Matern. Child Nutr. 12, 91-105. doi: $10.1111 / \mathrm{mcn} .12258$

Damania, R., Desbureaux, S., Rodella, A. S., Russ, J., and Zaveri, E. (2019). Quality Unknown: The Invisible Water Crisis. Washington, DC: World Bank. doi: 10.1596/978-1-4648-1459-4

Dao, J, Stenchly, K., Traoré, O., Amoah, P., and Buerkert, A. (2018). Effects of water quality and post-harvest handling on microbiological contamination of lettuce at urban and peri-urban locations of Ouagadougou, Burkina Faso. Foods 7:206. doi: 10.3390/foods7120206

de Lange, T., Linderhof, V., and Reinhard, S. (2021). Water Quality and Food Security Interactions: A Conceptual Framework Linking Food Systems and Water Quality Management Issues. Wageningen, the Netherlands: Wageningen Economic Research.

Djedjibegovic, J, Marjanovic, A., Tahirovic, D., Caklovica, K., Turalic, A., Lugusic, A., et al. (2020). Heavy metals in commercial fish and seafood products and risk assessment in adult population in Bosnia and Herzegovina. Sci. Rep. 10:13238. doi: 10.1038/s41598-020-70205-9

Dzwairo, B., Hoko, Z., Love, D., and Guzha, E. (2006). Assessment of the impacts of pit latrines on groundwater quality in rural areas: a case study from Marondera District, Zimbabwe. Phys. Chem. Earth Parts A/B/C 31, 779-88. doi: 10.1016/j.pce.2006. 08.031

Eltholth, M., Fornace, K., Grace, D., Rushton, J., and Häsler, B. (2015). Characterisation of production, marketing and consumption patterns of farmed Tilapia in the Nile Delta of Egypt. Food Policy 51, 131-143. doi: 10.1016/j.foodpol.2015.01.002

Ensink, J. H. J., Mahmood, T., van der Hoek, W., Raschid-Sally, L., and Amerasinghe, F. P. (2004). A nationwide assessment of wastewater use in Pakistan: an obscure activity or a vitally important one?' Water Policy 6, 197-206. doi: 10.2166/wp.2004.0013

FAO (2011). The State of the World's Land and Water Resources for Food and Agriculture: Managing Systems at Risk. Abingdon, VA: Earthscan [u.a.].

FAO (2016). Evaluation of Pesticide Residues for Estimation of Maximum Residue Levels and Calculation of Dietary Intake: Training Manual. 224 FAO Plant Production and Protection Paper. Rome, Italy: Food and Agriculture Organization of the United Nations. Available online at: http://www.fao.org/ 3/a-i5545e.pdf (accessed January 06, 2021).

FAO (2017). Water for Sustainable Food and Agriculture: A Report Produced for the G20 Presidency of Germany. Rome, Italy: Food and Agriculture Organization. Available online at: http://www.fao.org/documents/card/en/c/6dce4e64-43ab4728-ab18-59379a887e0a/ (accessed January 06, 2021).

FAO (2020). The State of World Fisheries and Aquaculture 2020. Rome, Italy: Food and Agriculture Organization of the United Nations.

FAO and IMWI (2017). Water Pollution from Agriculture: A Global Review (Executive Summary). Rome, Italy and Colombo, Sri Lanka: Food and Agriculture Organization of the United Nations and International Water Management Institute.

FAO and IWMI (2018). More People, More Food, Worse Water? A Global Review of Water Pollution from Agriculture. Rome, Italy and Colombo, Sri Lanka: Food and Agriculture Organization of the United Nations and International Water 
Management Institute. Available online at: https://reliefweb.int/sites/reliefweb. int/files/resources/CA0146EN.pdf (accessed December 08, 2020).

Funari, E., and Testai, E. (2008). Human health risk assessment related to cyanotoxins exposure. Critic. Rev. Toxicol. 38, 97-125. doi: $10.1080 / 10408440701749454$

Gasem, M. H., Dolmans, W. M. V. W. M. V., Keuter, M. M., and Djokomoeljanto, R. R. (2001). Poor food hygiene and housing as risk factors for typhoid fever in Semarang, Indonesia. Trop. Med. Int. Health 6, 484-490. doi: 10.1046/j.1365-3156.2001.00734.x

Graham, J. P., and Polizzotto, M. L. (2013). Pit latrines and their impacts on groundwater quality: a systematic review. Environ. Health Perspect. 121, 521-530. doi: 10.1289/ehp.1206028

Hach, C. V., and Tan, P. S. (2007). Study on site-specific nutrient management (SSNM) for high-yielding rice in the Mekong Delta. 15, 144-152.

Holvoet, K., Jacxsens, L., Sampers, I., and Uyttendaele, M. (2012). Insight into the prevalence and distribution of microbial contamination to evaluate water management in the fresh produce processing industry. J. Food Protect. 75, 671-681. doi: 10.4315/0362-028X.JFP-11-175

Hubbard, R. K., Newton, G. L., and Hill, G. M. (2004). Water quality and the grazing animal. J. Anim. Sci. 82, E255-E263. doi: $10.2527 / 2004.8213 \_s u p p l E 255 x$

Islam, A., Romić, D., Akber Md, A., and Romić, M. (2018). Trace metals accumulation in soil irrigated with polluted water and assessment of human health risk from vegetable consumption in Bangladesh. Environ. Geochem. Health 40 59-85. doi: 10.1007/s10653-017-9907-8

Jaishankar, M., Tseten, T., Anbalagan, N., Mathew, B. B., and Beeregowda, K. N. (2014). Toxicity, mechanism and health effects of some heavy metals. Interdiscip. Toxicol. 7, 60-72. doi: 10.2478/intox-2014-0009

Jawahar, P., and Ringler, C. (2009). Water quality and food safety: a review and discussion of risks. Water Policy 11, 680-695. doi: 10.2166/wp.2009.037

Jéquier, E., and Constant, F. (2010). Water as an essential nutrient: the physiological basis of hydration. Eur. J. Clin. Nutr. 64, 115-123. doi: $10.1038 /$ ejen.2009.111

Keraita, B., and Drechsel, P. (2015). Consumer Perceptions of Fruit and Vegetable Quality: Certification and Other Options for Safeguarding Public Health in West Africa. IWMI working paper 164. IWMI Working Paper. Colombo, Sri Lanka: International Water Management Institute (IWMI).

Khan, S., Cao, Q., Zheng, Y. M., Huang, Y. Z., and Zhu, Y. G. (2008). Health risks of heavy metals in contaminated soils and food crops irrigated with wastewater in Beijing, China. Environ. Pollut. 152, 686-692. doi: 10.1016/j.envpol.2007.06.056

Kim, K. H., Kabir, E., and Jahan, S. A. (2017). Exposure to pesticides and the associated human health effects. Sci. Total Environ. 575, 525-535. doi: 10.1016/j.scitotenv.2016.09.009

Kirby, R. M., Bartram, J., and Carr, R. (2003). Water in food production and processing: quantity and quality concerns. Food Control 14, 283-299. doi: 10.1016/S0956-7135(02)00090-7

Leip, A., Gilles, B., Josette, G., Bruna, G., Luis, L., Stefan, R., David, S., et al. (2015). Impacts of European livestock production: nitrogen, sulphur, phosphorus and greenhouse gas emissions, land-use, water eutrophication and biodiversity. Environ. Res. Lett. 10:115004. doi: 10.1088/1748-9326/10/11/115004

Littman, R. A., Fiorenza, E. A., Wenger, A. S., Berry, K. L. E., van de Water, J. A. J. M., and Nguyen, L. S., et al. (2020). Coastal urbanization influences human pathogens and microdebris contamination in seafood. Sci. Total Environ. 736:139081. doi: 10.1016/j.scitotenv.2020.139081

Liu, Y., Villalba, G., Ayres, R. U., and Schroder, H. (2008). Global phosphorus flows and environmental impacts from a consumption perspective. J. Indus. Ecol. 12, 229-247. doi: 10.1111/j.1530-9290.2008.00025.x

Lu, Z.-X., Heong, K. L, Yu, X.-P., and Hu, C. (2004). Effects of plant nitrogen on ecological fitness of the brown planthopper, Nilaparvata lugens Stal. in Rice. J. Asia-Pac. Entomol. 7, 97-104. doi: 10.1016/S1226-8615(08)60204-6

Mahmood, A., and Malik, R. N. (2014). Human health risk assessment of heavy metals via consumption of contaminated vegetables collected from different irrigation sources in Lahore, Pakistan. Arab. J. Chem. 7, 91-99. doi: 10.1016/j.arabjc.2013.07.002

Malakar, A., Snow, D. D., and Ray, C. (2019). Irrigation water quality-a contemporary perspective. Water 11:1482. doi: 10.3390/w11071482

Martínez-Cortijo, J., and Ruiz-Canales, A. (2018). Effect of heavy metals on rice irrigated fields with waste water in high PH Mediterranean soils: the particular case of the Valencia area in Spain. Agric. Water Manag. 210, 108-123. doi: 10.1016/j.agwat.2018.07.037

McIntosh, A., and Pontius, J. (2017). "Global water resources," In Case Studies for Integrating Science and the Global Environment (Amsterdam: Elsevier), 113-254. doi: 10.1016/B978-0-12-801712-8.00002-0

Mhlongo, T. N., Ogola, H. J. O., Selvarajan, R., Sibanda, T., Kamika, I., and Tekere, M. (2020). Occurrence and diversity of waterborne fungi and associated mycotoxins in treated drinking water distribution system in South Africa: implications on water quality and public health. Environ. Monitor. Assess. 192:519. doi: 10.1007/s10661-020-08477-x

Mihelcic, J. R., Fry, L. M., and Shaw, R. (2011). Global potential of phosphorus recovery from human urine and feces. Chemosphere 84, 832-839. doi: 10.1016/j.chemosphere.2011.02.046

Mrozik, W., Vinitnantharat, S., Thongsamer, S., Pansuk, N., Pattanachan, P., Thayanukul, P., Acharya, K., et al. (2019). The food-water quality nexus in peri-urban aquacultures downstream of Bangkok, Thailand. Sci. Total Environ. 695:133923. doi: 10.1016/j.scitotenv.2019.133923

Ndlela, L. L., Oberholster, P. J., Van Wyk, J. H., and Cheng, P. H. (2016). An overview of cyanobacterial bloom occurrences and research in Africa over the last decade. Harmful Algae 60, 11-26. doi: 10.1016/j.hal.2016. 10.001

Nordstrom, D. K. (2002). Public health: enhanced: worldwide occurrences of arsenic in ground water. Science 296, 2143-2145. doi: 10.1126/science.1072375

Nounkeu, C. D., and Dharod, J. M. (2020). A qualitative examination of water access and related coping behaviors to understand its link to food insecurity among rural households in the West Region in Cameroon. Int. J. Environ. Res. Public Health 17:4848. doi: 10.3390/ijerph17134848

Obayomi, O., Ghazaryan, L., Ben-Hur, M., Edelstein, M., Vonshak, A., Safi, J., et al. (2019). The fate of pathogens in treated wastewater-soil-crops continuum and the effect of physical barriers. Sci. Total Environ. 681, 339-349. doi: $10.1016 /$ j.scitotenv.2019.04.378

Omemu, A. M., and Aderoju, S. T. (2008). Food safety knowledge and practices of street food vendors in the city of Abeokuta, Nigeria. Food Control 19, 396-402. doi: 10.1016/j.foodcont.2007.04.021

Omwenga, I., Kanja, L., Nguta, J., Mbaria, J., and Irungu, P. (2016). Organochlorine pesticide residues in farmed fish in Machakos and Kiambu Counties, Kenya. Cogent Environ. Sci. 2:1153215. doi: 10.1080/23311843.2016.1 153215

Otte, J., Pica-Ciamarra, U., and Morzaria, S. (2019). A comparative overview of the livestock-environment interactions in Asia and Sub-Saharan Africa. Front. Vet. Sci. 6:37. doi: 10.3389/fvets.2019. 00037

Qadir, M., Wichelns, D., Raschid-Sally, L., Minhas, P. S., Drechsel, P., Bahri, A., et al. (2007). "Agricultural use of marginal-quality water- opportunities and challenges," in Water for Food, Water for Life. A Comprehensive Assessment of Water Management in Agriculture, ed. D. Molden (London, UK: Earthscan), 33. Available online at: https://hdl.handle.net/20.500.11766/8359 (accessed November 23, 2020).

Qasemi, M., Afsharnia, M., Farhang, M., Bakhshizadeh, A., Allahdadi, M., and Zarei, A. (2018). Health risk assessment of nitrate exposure in groundwater of rural areas of Gonabad and Bajestan, Iran. Environ. Earth Sci. 77:551. doi: $10.1007 / \mathrm{s} 12665-018-7732-8$

Rajmohan, N., and Prathapar, S. A. (2014). Extent of Arsenic Contamination and its Impact on the Food Chain and Human Health in the Eastern Ganges Basin: A Review. IWMI working paper 161. IWMI Working Paper. Colombo, Sri Lanka: International Water Management Institute (IWMI).

Rattan, R. K., Datta, S. P., Chhonkar, P. K., Suribabu, K., and Singh, A. K. (2005). Long-term impact of irrigation with sewage effluents on heavy metal content in soils, crops and groundwater-a case study. Agric. Ecosyst. Environ. 109, 310-322. doi: 10.1016/j.agee.2005.02.025

Ravenscroft, P., Mahmud, Z. H., Shafiqul Islam, M., Hossain, A. K. M. Z., Zahid, A., Saha, G. C., et al. (2017). The public health significance of latrines discharging to groundwater used for drinking. Water Res. 124, 192-201. doi: 10.1016/j.watres.2017.07.049

Sebesvari, Z., Le, H.T.T., Toan, P. V., Arnold, U., and Renaud, F. G. (2012). "Agriculture and water quality in the Vietnamese Mekong Delta," in The Mekong Delta System (Berlin: Springer Environmental Science and Engineering), 331-361. 
Shalaby, S. E. M., El-Saadany, S. S., Abo-Eyta, A. M., Abdel-Satar, A. M., Al-Afify, A. D. G., and Abd El-Gleel, W. M. M. (2018). Levels of pesticide residues in water, sediment, and fish samples collected from Nile River in Cairo, Egypt. Environ. For. 19, 228-238. doi: 10.1080/15275922.2018.1519735

Sharma, R. K., Agrawal, M., and Marshall, F. (2006). Heavy metal contamination in vegetables grown in wastewater irrigated areas of Varanasi, India. Bull. Environ. Contam. Toxicol. 77, 312-318. doi: 10.1007/s00128-006-1065-0

Sharma, S., and Bhattacharya, A. (2017). Drinking water contamination and treatment techniques. Appl. Water Sci. 7, 1043-1067. doi: 10.1007/s13201-016-0455-7

Siebe, C., and Cifuentes, E. (1995). Environmental impact of wastewater irrigation in Central Mexico: an overview. Int. J. Environ. Health Res. 5, 161-173. doi: 10.1080/09603129509356845

Singh, A., Sharma, R. K., Agrawal, M., and Marshall, F. M. (2010). Health risk assessment of heavy metals via dietary intake of foodstuffs from the wastewater irrigated site of a dry tropical area of India. Food Chem. Toxicol. 48, 611-619. doi: 10.1016/j.fct.2009.11.041

Spears, D., Ghosh, A., and Cumming, O. (2013). Open defecation and childhood stunting in India: an ecological analysis of new data from 112 districts. PLoS ONE 8:e73784. doi: 10.1371/journal.pone.0073784

Steele, M., and Odumeru, J. (2004). Irrigation water as source of foodborne pathogens on fruit and vegetables. J Food Protect. 67, 2839-2849. doi: 10.4315/0362-028X-67.12.2839

Sun, C., Chen, L., Zhai, L., Liu, H., Jiang, Y., Wang, K., et al. (2019). National assessment of spatiotemporal loss in agricultural pesticides and related potential exposure risks to water quality in China. Sci. Total Environ. 677, 98-107. doi: 10.1016/j.scitotenv.2019.04.346

Szabo, J., and Minamyer, S. (2014). Decontamination of biological agents from drinking water infrastructure: a literature review and summary. Environ. Int. 72, 124-128. doi: 10.1016/j.envint.2014.01.031

Tauxe, R. V. (2002). Emerging foodborne pathogens. Int. J. Food Microbiol. 78, 31-41. doi: 10.1016/S0168-1605(02)00232-5

Toan, P. V., Sebesvari, Z., Bläsing, M., Rosendahl, I., and Renaud, F. G. (2013). Pesticide management and their residues in sediments and surface and drinking water in the Mekong Delta, Vietnam. Sci. Total Environ. 452-453:28-39. doi: 10.1016/j.scitotenv.2013.02.026

Touil, S., Chabaca, M. N., and Hasbaia, O. (2020). Impact assessment of long treated wastewater irrigation on soil and crops in Algeria. Euro-Mediterr. J. Environ. Integr. 5:65. doi: 10.1007/s41207-020-00187-7

Tsai, W.-T. (2019). Trends in the use of glyphosate herbicide and its relevant regulations in taiwan: a water contaminant of increasing concern. Toxics 7:4. doi: $10.3390 /$ toxics7010004

Tusseau-Vuillemin, M-H. (2001). Do food processing industries contribute to the eutrophication of aquatic systems? Ecotoxicol. Environ. Saf. 50, 143-152. doi: $10.1006 /$ eesa.2001.2083

UNEP (2016). Snapshot of the World's Water Quality: Towards a Global Assessment. Nairobi, Kenya: United Nations Environment Programme. Available online at : https://www.unep.org/resources/ publication/snapshot-report-worlds-water-quality (accessed March 07, 2020).

Valta, K., Kosanovic, T., Malamis, D., Moustakas, K., and Loizidou, M. (2015). Overview of water usage and wastewater management in the Food and Beverage Industry. Desalinat. Water Treat. 53, 3335-3347. doi: 10.1080/19443994.2014.934100

van Berkum, S., Dengerink, J., and Ruben, R. (2018). The Food Systems Approach: Sustainable Solutions for a Sufficient Supply of Healthy Food.
No. 2018-084. Economic Research Memorandum. The Hague: Wageningen Economic Research. doi: 10.18174/451505

Vázquez, M., Calatayud, M., Jadán Piedra, C., Chiocchetti, G. M., Vélez, D., and Devesa, V. (2015). Toxic trace elements at gastrointestinal level. Food Chem. Toxicol. 86, 163-175. doi: 10.1016/j.fct.2015.10.006

Walker, S. (2019). In World That Says It's Cutting Nutrient Pollution, Progress Is Lacking. World Resource Institute (blog). Available online at: https://www.wri. org/blog/2019/03/world-says-its-cutting-nutrient-pollution-progress-lacking (accessed April 3, 2019).

Wardrop, N. A., Hill, A. G.,Dzodzomenyo, M., Aryeetey, M., and Wright, J. A. (2018). Livestock ownership and microbial contamination of drinkingwater: evidence from nationally representative household surveys in Ghana, Nepal and Bangladesh. Int. J. Hyg. Environ. Health 221, 33-40. doi: 10.1016/j.ijheh.2017.09.014

Waturangi, D. E., Wennars, M., Suhartono, M. X., and Wijaya, Y. F. (2013). Edible ice in Jakarta, Indonesia, is contaminated with multidrug-resistant vibrio cholerae with virulence potential. J. Med. Microbiol. 62, 352-359. doi: 10.1099/jmm.0.048769-0

WHO (2017). Safely Managed Drinking Water-Thematic Report on Drinking Water. Geneva, Switzerland: World Health Organization. Available online at: https://washdata.org/report/jmp-2017-tr-smdw (accessed January 11, 2021).

WHO (2020). Food safety. Available online at: https://www.who.int/news-room/ fact-sheets/detail/food-safety (accessed April 30, 2020).

Willett, W., Rockström, J., Loken, B., Springmann, M., Lang, T., Vermeulen, S., Garnett, T., et al. (2019). Food in the Anthropocene: the EAT-Lancet commission on healthy diets from sustainable food systems. Lancet 393, 447-492. doi: 10.1016/S0140-6736(18)31788-4

Woldetsadik, D., Drechsel, O., Keraita, B., Itanna, F., and Gebrekidan, H. (2018). 'Farmers' perceptions on irrigation water contamination, health risks and risk management measures in prominent wastewater-irrigated vegetable farming sites of Addis Ababa, Ethiopia. Environ. Syst. Decis. 38, 52-64. doi: 10.1007/s10669-017-9665-2

Yabe, J., Ishizuka, M., and Umemura, T. (2010). Current levels of heavy metal pollution in Africa. J. Vet. Med. Sci. 72, 1257-1263. doi: 10.1292/jvms.10-0058

Zain, M. E. (2011). Impact of mycotoxins on humans and animals. J. Saudi Chem. Soc. 15, 129-144. doi: 10.1016/j.jscs.2010.06.006

Conflict of Interest: The authors declare that the research was conducted in the absence of any commercial or financial relationships that could be construed as a potential conflict of interest.

Publisher's Note: All claims expressed in this article are solely those of the authors and do not necessarily represent those of their affiliated organizations, or those of the publisher, the editors and the reviewers. Any product that may be evaluated in this article, or claim that may be made by its manufacturer, is not guaranteed or endorsed by the publisher.

Copyright (C) 2021 Linderhof, de Lange and Reinhard. This is an open-access article distributed under the terms of the Creative Commons Attribution License (CC BY). The use, distribution or reproduction in other forums is permitted, provided the original author(s) and the copyright owner(s) are credited and that the original publication in this journal is cited, in accordance with accepted academic practice. No use, distribution or reproduction is permitted which does not comply with these terms. 